\title{
RURAL SOCIETIES WITH INDUSTRIAL WORKERS IN NORTHEAST HUNGARY
}

\author{
PÉTER ALABÁN \\ Eszterházy Károly College \\ E-mail: alaban.peter@gmail.com
}

\begin{abstract}
The sphere of analysis in this article includes settlements in the north of Hungary. They are located in the north of Borsod-Abaúj-Zemplén County, in the area that attracted a labor force to the former Metallurgical Works of Ózd. The most considerable stratification of society of the rural and poor noble population that lived in the settlements neighboring Ózd, which was inhabited since the Middle Ages, happened when in the former industrial town the demand for the labor force of the gradually expanding works extended and changed the society of the neighboring villages. After 1945, the process continued, and it attracted the inhabitants of the settlements located within a 50 kilometer radius to take part in industrial employment. Metallurgy, which offered a secure, permanent living as well as mining, which was typical of the region, formed laborers and miners from the native peasants living close to migrating workers and sometimes created dynasties of workers through several generations. The employment of women came to the fore in time: apart from housekeeping, which was demanding, the girls and mothers could do heavy manual work, so they appeared on the labor market as earners as well.
\end{abstract}

Keywords: urban history, Hungary, Ózd, social stratification, socialism, demographic shift, urbanization

The analysis of the industrial, building, transport and trade sectors, and within these the categorization according to profession and position provides an opportunity to monitor, compare and draw conclusions from the changes that took place after the socialist era and the years following the change of regime. The formation of manufacturing industry and the working class in the industrial sector took place even in the second half of the $19^{\text {th }}$ century, however, escape into mining had similar effects on impoverished masses of former peasants especially in the first waves of stratification. From the second half of the $20^{\text {th }}$ century these phenomena became common nationwide, the world of rural societies changed, at the same time the stratum of industrial workers included new elements. Accordingly, the participants of labor market showed a complex image. Looking through their groups according to employment a significant stratification among the gen- 
erations can be noticed within a short period of time. The intra- and intergeneration analyses represent the importance of industrial employment, the break-up of the traditional peasant world, the changes in lifestyle, the trauma caused by the cutback of heavy industry as well as the disappearance of traditional social groups (e.g. peasantry, industrial workers). In the early $21^{\text {st }}$ century we can notice the gradual downtrend of labor market as well as the revaluation of the service sector despite the decreasing demand. The transition from Socialism into a market economy created insurmountable problems in several regions, mostly in the fields of economic restructing, employment, unemployment and social composition. The picture is especially depressing in the northern region of Hungary, in the once flourishing settlements relying on mining and heavy industries, which had provided them with certain livelihood. The study focuses on villages surrounding the city of Ózd, where the survival and sustenance of the population was directly threatened by closure of factories, plants and mines in the area. The common features of these settlements often include social restructuring, negative migration due to manifold reasons such as demographic processes and the lack of employment opportunities, deep poverty and subsequent social ghettoisation, the gradual deterioration and disintegration of cultural and educational facilities, and last but not least, a hopeless vision for the future.

\section{The Factory of Ózd}

The demographics and social composition of the district of Ózd was shaped by various historical factors. Industrialisation, which began in the mid-nineteenth century, followed by world wars, annexation, land reforms, forced industrialisation and reorganisation of agriculture, and finally the crisis and liquidation of heavy industries, were determinative for the lives of the people living in the region in the past hundred years. In the $20^{\text {th }}$ century, intensive immigration to the region caused a major population increase, which eventually gave way to a dramatic decrease due to the regression of the iron industry after the middle of the 1980s.

The "Gömöri Vasmüvelö Egyesület”, established in the May of 1845, as well as the factory being in the process of construction from the following year immediately became an influence on the life of Ózd, which was then a small village only inhabited by 350, in the middle of the $19^{\text {th }}$ century. In 1881 the Rimamurány-Salgótarján Ironworks Plc. was established through merging and it brought a dynamic development to the works of Ózd. The expansion of capacity brought about the upsurge of coal mining and mining communities. At the turn of the century there were more and more neighboring settlements with stratification: Sajóvárkony, Arló, (Borsod)Bóta, Csernely, the later connected Csokva and 
Omány, Bükkmogyorósd and (Lénárd)Daróc. They rapidly became mining settlements while the number of their populations started to increase. (Sárközi, Z. 1980. 90.)

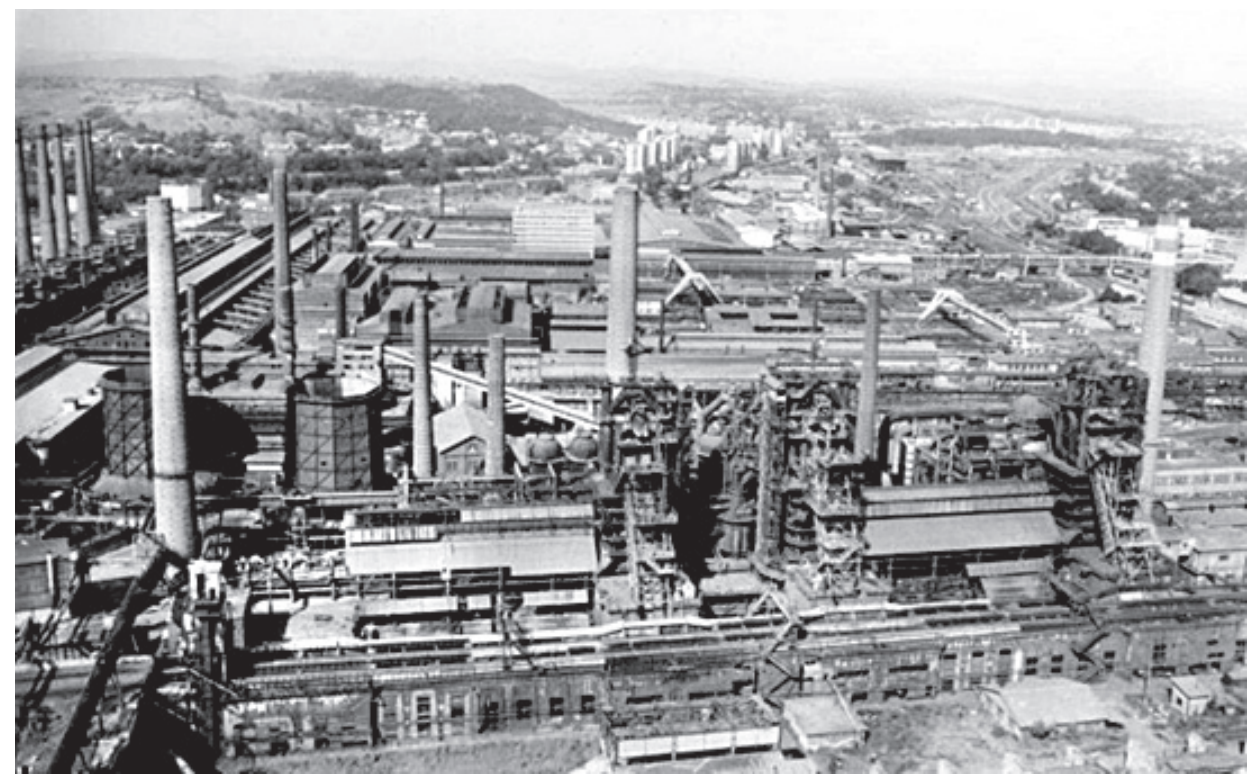

The factory viewed from above. Photo by Dobosy, László. Ózd, 1992

Statistics also refer to the way industry gained ground. One of the examples can be Arló, situated 3 kilometers outside of Ózd. The population of Arló in 1890 was only 1,458, in 1900 it was 1,679, in 1910 it was 1,954, in 1920 it was 2,095, in 1930 it was 2,625, and in 1941 it was as many as 3,147. The increase within half a century was 53.7 percent! (Population Census, 1932. 63.; 1947. 52.) The reversal of employment is indicated by the gradual decline in number and proportion of local farmers earning their living from agriculture despite the constant growth in the number of members and in 1930 only 31.2 percent (304 people) belonged to this category out of all the earners (973 people). It was a significant decrease of more than 10 percent comparing to the previous census (in 1920 it was 42.1 percent). (Population Census, 1925. 108.; 1934. 73.) After the cessation of mining Arló gave the biggest proportion of commuting workers of the Metallurgical Works of Ózd in the mid-1970s, so industrial work only changed in form, its importance regarding secure living had been determining until the change of regime. The lifestyle changed and the shifts of earlier 16, 12, and finally 8 hours governed the rhythm of the life of manufacturing, mining colonies and industrial workers.

Along with social changes an unique labor market evolved with workers mainly coming from villages whose inhabitants were engaged in agriculture. They 
became later skilled workers, unskilled workers or semi-skilled workers in the factory, but majority of them came from peasant families with peasant parents. The local societies changed and the agricultural population restratified. Due to the changes it was not possible to prevent traditional peasant family models from disintegrating. By the middle of the $19^{\text {th }}$ century, 35 percent of industrial labor worked in the city of Ózd but at the end of the century the factory was providing work for the inhabitants of 28 settlements, which accounted for more than 44 percent of the labor force then. In 1955 industrial manpower employed in Ózd exceeded the 13,000 mark and while 7,000 workers were local residents, over 45 percent of the workforce commuted daily from the villages of the industrial area. (Kóródi, J. 1959. 245.) In 1975 there were commuters already from 55 villages to Ózd, and their number increased to 4,650. (Dömötör, Á. 1997. 615.) The important role of the factory is clear-cut: with 1,350 workers the above mentioned settlements, which were 7-8 kilometers away from Ózd, gave a third of the commuting workers. One of the settlements, Arló, belonged the region where commuting took place at the turn of the $19^{\text {th }}$ and $20^{\text {th }}$ centuries, therefore it can be considered as one of the first settlements where stratification of society appeared. In 1975 there were 1,050 locals working in the factory, there was a strong differentiation among them: from simple cleaners to engineers, we could find local people in all positions. (Papp, E. 1976. 83-84.) There were workers from Arló not only in the Borsodnádasd Factory of Plates but also in other smaller factories.

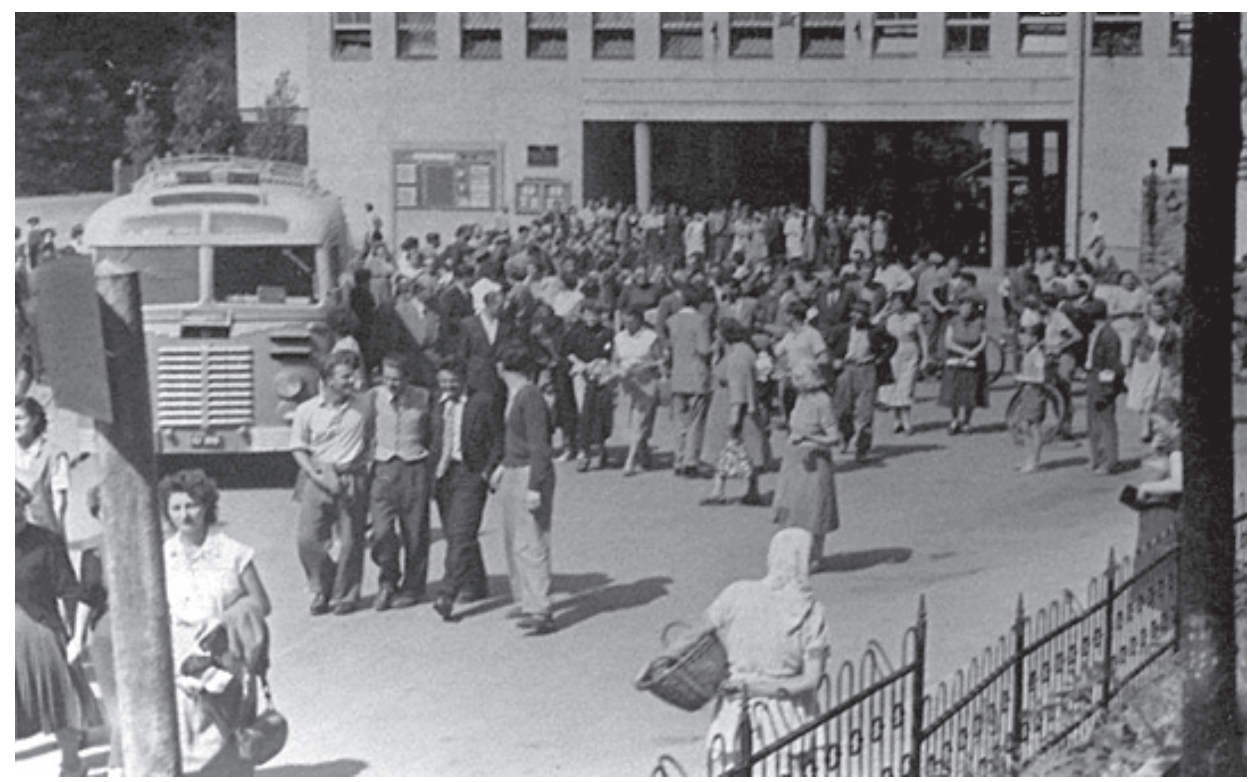

End of the shift. Photo from a private collection. Borsodnádasd, 1960s 
In the mid-1970s, 72 percent of the population in the region of Ózd worked in industry while the proportion of those working in agriculture fell to 13.3 percent. The number of commuting workers was high: according to one of the reports it reached 1,200 at the Borsodnádasd Factory of Plates and in the working coal mines it was 1,500 people. (Vodila, B. 1976. 79.) All the same, fluctuation was high and there were several sources to back it up: before 1970 we can talk about migration within the walls of the factory, but after that it was the leaving of workers from the factory that often caused problems. (Tóth, P. 1980. 432.)

During the 1970s shortage of steel in Hungary, the steel industry continued to use obsolete technologies and the product structure was never reorganised to satisfy the demands of international markets. By the 1990s, mining ceased altogether, heavy industry plants stopped operation, and the Ózd Metal Works was divided into parts, and even their successors are long gone by now. Besides Ózd itself, the agglomeration and nearby settlements were in the same position: their development ground to a halt, new opportunities were hard to find. Contrary to the national tendencies at the time, the job market entered an unfavourable phase. While the number of pensioners was above national average, the majority of the unemployed were young (under 35 ) with no education and technical skills. With the disappearance of the formerly prevalent metal and mining industries, the reemployment of people over 40 became very difficult. Although the number of registered unemployed dropped between 1995 and 2005, the figures were still very high in January 2005 (nearly 5,000 people), and the situation has not improved since then.

In the following I will analise the local phenomena of social changes and take as examples two settlements lying in the valley of Hangony creek emphasizing the common features and the main differences. During the economic and political transformation following the change of regime the former socialist economic cooperative system fell apart. The export of Hungarian agriculture, which was in financial difficulties, was no longer able to provide the transport of raw materials and energy which were necessary for smelting and the manufacturing of materials in chemical industry. The low prices, the losing of markets, uneconomical production and finally the reconstruction of structure which failed to happen all aggravated the situation. In order to control losses support for export was ceased, the transformation of the structure of production and employment became important. By the 1990s, the metallurgical and mining industry ceased to exist, the heavy industrial factories stopped, the Metallurgical Works of Ózd fell apart. The outskirts of the city and its surroundings got into the same situation, too, their development has stopped, new chances arose only in a few places.

In the spring of 1991 iron industry of crude iron ceased in Ózd while procedures of privatization, bankruptcy and liquidation proceedings started across the country. (Vass, T. 2003. 100, 104.) Unemployment gradually increased and at the same 
time demographic figures deteriorated: the mortality rate is high and increasingly less and less children are born, the number of emigrants grew, the population of the town and its area decreased, the standard of living declined. In a statistical respect 1993 was a trough when the number of registered unemployed approximated the number of former factory workers of Ózd exceeding 12 thousand.

\section{Analyses of Settlements in the Hangony Valley I. Domaháza}

One of the most important centers of the eastern "Palóc" ethnic minority where tradition is kept is definitely Domaháza. The westernmost settlement of BorsodAbaúj-Zemplén County is situated near the Slovak border, 17 kilometers from Ózd. According to the documentary evidence, Domaháza had existed by the $13^{\text {th }}$ century and lies in an ethnographic region called Barkóság with eastern Palóc groups. Its population reached 1,000 only after the First World War, then in 1960 the maximum number of population was 1,286, but since then it has been continuously decreasing, today only 950 people live there. Its surroundings are hilly, the ground here is sterile, the fields are of poor quality and hard to cultivate. Accordingly, its farming was self-sufficient, there was no real possibility to produce goods for markets. Despite the village's bad conditions the population of the settlement was engaged in agriculture and animal keeping through centuries.

The former noble families, who lived as peasants, were mostly engaged in animal husbandry, industrial work had not been typical in the settlement before 1945. In the socialist system, with the abolishment of private property more and more people left their lands and became factory workers at the works of Ózd. The population of Domaháza grew gradually through the years and in 1920 it reached 1,000, and after the Second World War at the time of a census held on 1st January 1949 the number was 1,182. Domaháza can be considered enclosed. It is clear from the fact that unlike other settlements neighboring Ózd the proportion of those who earned their living from agriculture was still bigger.

The changes of the "Kádár-era" (1956-1988) made essential impacts on the structure of families and the employment distribution. In 1960 the number of local inhabitants reached the so-called "demographic peak" which was 1,286 people, the majority of which were women.

With the 367 families the proportion of dependents was 10 percent higher than that of the earners and it refers to the natural progeny and the make-up of people which was not senescent yet. It must be emphasized that there was a most considerable and dynamic change in the structure of employment by comparison with the time of the previous census: regarding the distribution of earners agriculture came in the second position (33.9 percent) with an enormous 
decline while the proportion of industrial and construction workers, which increased simultaneously, came to the top (with a total of 51.5 percent!) (Population Census, 1961. 97.)

Table 1. Population by economic branch in Domaháza (1960-1980)

\begin{tabular}{lcccccc}
\hline & \multicolumn{2}{c}{1960} & \multicolumn{2}{c}{1970} & \multicolumn{2}{c}{1980} \\
\cline { 2 - 7 } & Person & percent & Person & percent & Person & percent \\
\hline $\begin{array}{l}\text { Agricultural, } \\
\text { sylviculture }\end{array}$ & 282 & 46.8 & 199 & 37.1 & 82 & 19.2 \\
$\begin{array}{l}\text { Industry, building } \\
\text { industry }\end{array}$ & 225 & 37.4 & 281 & 52.4 & 272 & 63.6 \\
Transportation & 16 & 2.6 & 11 & 2.1 & 16 & 3.7 \\
Trade & 9 & 1.6 & 21 & 3.9 & 22 & 5.1 \\
Other & 70 & 11.6 & 24 & 4.5 & 36 & 8.4 \\
\hline Total & 602 & 100 & 536 & 100 & 428 & 100 \\
\hline
\end{tabular}

(Population Census, 1961. 183, 196-197.; 1972. 550.; 1981. 735.)

After dealing with the problems of distance and the appearance of bus transport there was a remarkable growth in the number of industrial workers. In 1949 there were only 64, in 1960 already 224 and in 1975 there were 228 workers of Domaháza who worked in one of the departments of the Metallurgical Works of Ózd most of them commuting on a daily basis. According to the data from the year 1960 most of these commuters worked at transport factories. At the time of the transformation of structure concerning heavy industry, it was around the mid-1980s, there were 516 wage earners in the village a great proportion (77 percent - 395 people) of whom worked at the works. The period between 1990 and 2001, however, looks quite different: the number of unemployed (32 and 117 people) grew appreciably and it proved to be permanent. (Population Census, 1990; 2001) ${ }^{1}$

The factory itself and its close-down had its effect both on the local communities and families. Now there is no producers' cooperative, no factory. The future of the village has probably never been so insecure as today. Meanwhile, the local society has transformed: without work and secure living the youth move away, the number of elderly people is high, and at the same time there is a great number of Roma who are buying the cheap properties but are without qualifications, education and work. 


\section{Analyses of Settlements in the Hangony Valley II. Hangony}

This settlement is also one of the villages among Palóc settlements and its natural environment was not particularly favorable for the predominantly farming and stockbreeding Roman Catholic population. Protestantism could not appear here, it became a completely Catholic settlement. The village is a good example for the effect that distance from the factory had. In Hangony, which is situated just 9 kilometers from Ózd and therefore it is closer than Domaháza, the stratification of society took place with similar intensity to Szentsimon, which became part of Ózd in 1979, earlier than in Domaháza. The village that was located on the southern border of the former Gömör hundred (a county in the Middle Ages under the control of a castle) had a population of 1,6392 people at the beginning of 2013.

The village had formerly been inhabited by nobles and villeins and consisted of two individual parts (Felsőhangony and Alsóhangony), which were administratively joined only in 1939. Industry soon attracted the local peasants who owned just a few lands: for instance in 1930 in Alsóhangony, which belonged to the district of Putnok in the county, 28 percent (386 people) of earners worked in industry and this proportion was similar among the businesspeople of Felsöhangony (382 people). (Population Census, 1934. 73.) 1,076 people lived in Domaháza in that year and only 5 percent of this number were engaged in industry, whereas in Szentsimon out of 950 people it was 30 percent. After the two parts of Hangony had united it became part of the district of Ózd and by 1949 the majority of workers were employed in industry here too. Industrial workers could only outnumber other workers in the second half of the "Kádár-era": at the time of the census in 1980 the proportion of those working in agriculture was only 15 percent, consequently the process of stratification was over.

In the 1970s Hangony became one of the villages of traditional labor reserve of the metal industry, too, and it had many workers commuting daily by bus. The majority of them came from peasant families so the local society changed and the agricultural population restratified while the number of inhabitants was more than 1,900 in 1960 and 1,873 in 1970. The settlement then exceeded the so-called "demographic peak" (1,970 people), but the number of those really living there started to fall: in 1970 it was 1,892, in 1980 it was 1,803, and in 1990 1,753 people lived in Hangony. (Population Census, 1992. 309.)

In consequence of the changes the collective effects of both commuting and the factory as well as the town integrated the lifestyle of the people of Hangony. In 1980, ahead of Szentsimon, Hangony gave the second most commuters (514) to Ózd. Most of them were naturally blue-collar workers employed in industry. Comparing them to their parents or grandparents it is clear that there was a transition and a change in occupation, so most of the fathers of commuters from Hangony were attached to agriculture, forestry: there were shepherds, servants, day labor- 


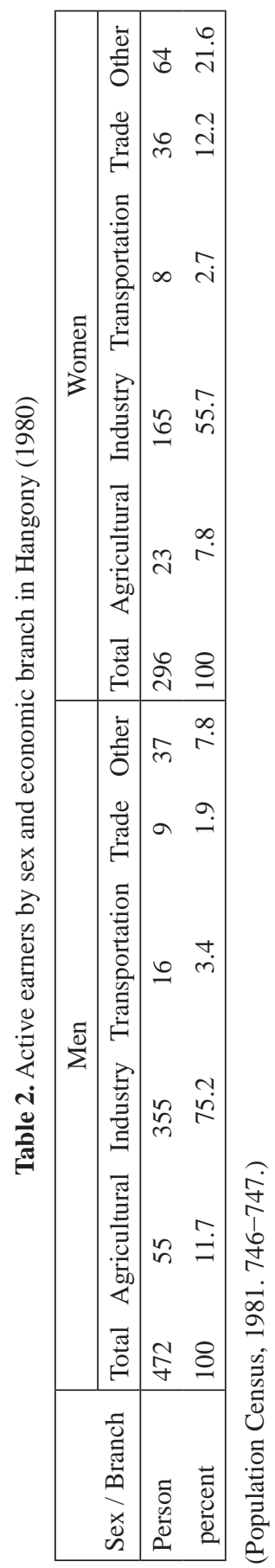


ers, peasants, woodmen among them. The prestige of qualification was revalued in time, since by the 1980s there were more and more skilled workers (248 people) among them, and even workers who held positions in directorates and managements (18 people). (Commuting, 1983. 634-635.) At that time, in the villages of Hangony Valley two major occupational groups lived together: the agricultural population working locally (or in agricultural cooperative farms) and the industrial workers (e.g. metalworkers, smelters), who commuted to the iron factory of Ózd.

The traditional family model also changed: the strict wedding (and religious) endogamy, which was typical of the eastern "Palóc" ethnic minority, was pushed into the background, and as a result, unmarried men and women could choose their partners from other settlements. The survey of Ákos Dömötör ethnographer in 1976 emphasized these processes in the neighborhood of Ózd, and while other settlements did not experience such changes the proportion of such "events" was 20 percent in Hangony. The choice of partners became exogamous: in one of the neighboring settlements, Kissikátor, nearly two-thirds of the commuting factory workers chose local partners, while in Hangony this proportion was only 46.4 percent. (Dömötör, Á. 1994. 380.)

At the same time with the disappearance of endogamy and the stratification of the local society the traditions of ethnic culture were gradually losing their importance, the traditional peasant world sank into oblivion. Achieving middle-class status was dilatory and as a result the functional system of family transformed, the former large families were replaced by smaller families of workers, the factory (place of work) became the center of communication and information stream, within the previously closed community the giving of tradition and the reception of culture heightened. Most of the women who had been previously engaged in housekeeping started to work together with men. Among the workplaces was the branch of Debrecen Clothes Factory in Ózd, or other smaller factories (for instance in Hangony) where most local women could find employment and consequently they could contribute to the upkeep of their families as well as the income of the household. Meanwhile, light industry became a branch of industry that could employ a considerable number of people. With the change of regime this - similarly to heavy industry - also ended: in the April of 1990 the press reported the gathering of workers, and finally the clothes factory of Ózd closed down.

\section{References}

Commuting. 1983. Az 1980. évi népszámlálás 33. Az aktív keresők munkahelye és lakóhelye. A naponta ingázók adatai. Központi Statisztikai Hivatal, Budapest (Population census 1980. The workplace and the residence of the active earners. Data of the daily commuting workers. Central Statistical Office. Budapest) 
Dömötör, Ákos. 1994. A Hangony-völgyi bejáró munkások a hetvenes években: néprajzi változásvizsgálat. In: Veres, L.-Viga, Gy. (szerk.): A Herman Ottó Múzeum Évkönyve XXXII. Herman Ottó Múzeum, Miskolc, 373-392. (Commuting workers in the Hangony basin in the 1970s: Ethnographic change research. In: Veres, László-Viga, Gyula eds: Annals of Ottó Herman Museum XXXII. Miskolc)

Dömötör, Ákos. 1997. Az ipari termelés hatása a Hangony-völgyi emberre. Jelenkor - történeti és néprajzi vizsgálat a 70-es évek első felében Ózd környékén. In: Veres László-Viga Gyula (szerk.): A Herman Ottó Múzeum Évkönyve XXXV-XXXVI. Herman Ottó Múzeum, Miskolc, 615-632. (The influence of industrial production on man in the Hangony basin. Investigation of historical and social anthropological variability in the 1970s. In: Veres, László-Viga, Gyula eds: Annals of Ottó Herman Museum XXXV-XXXVI. Miskolc)

Kóródi, József. 1959. A borsodi iparvidék. Közgazdasági és Jogi Könyvkiadó, Budapest (The Industrial Area of Borsod. Budapest)

Papp, Emil. 1976. A bejáró dolgozók helyzete Arló községben. In: Borsodi Szemle. 3. 83-85. (The situation of the commuting workers in Arló. In: Borsodi Szemle 3.)

Population Census. 1925. Az 1920. évi népszámlálás. Második rész. A népesség foglalkozása és a nagyipari és kereskedelmi vállalatok községenkint. In: Magyar Statisztikai Közlemények. Új sorozat. 71. kötet. Magyar Kir. Központi Statisztikai Hivatal, Budapest (Population census 1920. Part 2. In: Magyar Statisztikai Közlemények. New series. Book 71. Central Statistical Office. Budapest)

Population Census. 1932. Az 1930. évi népszámlálás. I. rész. Demográfiai adatok községek és külterületi lakotthelyek szerint. In: Magyar Statisztikai Közlemények. Új sorozat. 83. kötet. Budapest (Population census 1930. Part 1. In: Magyar Statisztikai Közlemények. New series. Book 71. Central Statistical Office. Budapest)

Population Census. 1934. Az 1930. évi népszámlálás. Második rész. A népesség foglalkozása és a nagyipari és kereskedelmi vállalatok községenkint. In: Magyar Statisztikai Közlemények. Új sorozat. 86. kötet. Magyar Kir. Központi Statisztikai Hivatal, Budapest (Population census 1930. Part 2. In: Magyar Statisztikai Közlemények. New series. Book 86. Central Statistical Office. Budapest)

Population Census. 1947. Az 1941. évi népszámlálás. Demográfiai adatok községek szerint. Központi Statisztikai Hivatal, Budapest (Population census 1941. Demographic data of the villages. Central Statistical Office. Budapest)

Population Census. 1961. Az 1960. évi népszámlálás 3. g. Borsod-Abaúj-Zemplén megye és Miskolc személyi és családi adatai. Központi Statisztikai Hivatal, Budapest (Population census Population Census.1960. 3. g. The personal and family data of Borsod-Abaúj-Zemplén County and Miskolc. Central Statistical Office. Budapest)

Population Census. 1981. Az 1980. évi népszámlálás 5. Borsod-Abaúj-Zemplén megye adatai. Központi Statisztikai Hivatal, Budapest (Population census 1980. Data of Borsod-Abaúj-Zemplén County. Central Statistical Office. Budapest)

Population Census. 1992. Az 1990. évi népszámlálás 7. Borsod-Abaúj-Zemplén megye adatai. Központi Statisztikai Hivatal, Budapest (Population census 1990. Data of Borsod-Abaúj-Zemplén County. Central Statistical Office. Budapest)

Sárközi, Zoltán. 1980. A Vasgyár és a szénbányászat tájátalakító hatása és a település fejlődése. In: Berend T. Iván (szerk.): Az Ózdi Kohászati Üzemek története. Ózdi Kohászati Üzemek, Ózd, 88-99. (The effect of the iron factory and the coal mining on the landscape and the development of the settlement. In: Berend, T. Iván ed.: The History of the Metallurgical Works of Ózd. Ózd)

Tóth, Pál. 1980. Az Ózdi Kohászati Üzemek korszerüsítésének első korszaka (1957-1970). In: Berend T. Iván (szerk.): Az Ózdi Kohászati Üzemek története. Ózdi Kohászati Üzemek, Ózd, 
345-433. (The first period of the modernisation of the Metallurgical Works of Ózd 1957-1970. In: Berend, T.Iván ed.: The History of the Metallurgical Works of Ózd. Ózd

Vass, Tibor. 2003. Az ózdi nyersvasgyártás története 1906-1996. Miskolc (The history of the pigiron production of Ózd. Miskolc)

Vodila, Barna. 1976. Az ózdi járás bejáró dolgozóiról. In: Borsodi Szemle 3. 78-83. (About the commuting workers in the Ózd region. In: Borsodi Szemle 3.)

\section{Notes}

1 http://www.nepszamlalas.hu/hun/kotetek/06/05/data/tabhun/4/load02_1_2.html; http://www.nepszamlalas.hu/hun/kotetek/06/05/data/tabhun/4/load02_1_3.html (Last download: March 2012)

2 http://www.ksh.hu/apps/hntr.telepules?p_lang=HU\&p_id=25104 (Last download: March 2014) 